Case Report

\title{
Henoch-Schonlein Purpura (HSP)
}

\author{
Lucia Pudyastuti Retnaningtyas ${ }^{1 *}$ \\ ${ }^{1}$ Fakultas Kedokteran, Universitas Surabaya, Surabaya-Indonesia \\ *corres ponding author: luciaretnaningtyas@staff.ubaya.ac.id
}

\begin{abstract}
Henoch-Schonlein purpura (HSP) is a systemic vasculitic disease (vascular inflammation) characterized by the deposition of immune complexes consisting of IgA in kidney skin. This disease is called Ana phylactoid purpura, rheumatic Purpura, Schonlein-Henoch purpura. In this case, the patient complained of the appearance of red spots on the legs to the buttocks within three days and did not feel itchy. Ankle pain and can not be moved, and do not feel nausea, fever, heartburn, and others. Examination of the extremities contained red lesions and was more prominent than other skin surfaces. Diagnosis of patients suspected of having Henoch-Schonlien purpura. Treatment of HSP patients with Prednisone at a dose of $2 \mathrm{mg} / \mathrm{kg} / \mathrm{day}$ which is divided into three doses. On the third-day purpura decreases tend to thin out and enkle pain disappears on the fifth day. Red spots appear, after therapy is stopped for 1 month. HSP sufferers $94 \%$ recover in children and $89 \%$ in adults. HSP recuration is more common in children over the age of 10 years and a kidney biopsy must be performed to determine subsequent therapy.
\end{abstract}

Keywords: henoch-schonlein purpura, steroid, palpable-purpura

Abstrak-Henoch-Schonlein purpura (HSP) ada lah penya kit va skulitik sistematik (inflamasi vaskuler) ditandai dengan deposisi komplek imun yang terdiri dari IgA pa da kulit ginjal. Penyakit ini disebut Ana phylactoid purpura, Purpura rheumatic, SchonleinHenoch purpura. Pada kasus ini pasien mengeluh timbulnya bercak merah pada kaki sa mpai bagian pantat dalam waktu tiga hari dan tidak merasa gatal-ga tal. Pergelangan kaki nyeri dan tidak bisa digerakkan, serta tidak merasa mual, demam, nyeri ulu hatidan lain-lain. Pemeriksaan ekstremitas terdapat lesi merah dan lebih menonjol dibandingkan premukaan kulit lain. Diagnosa pasien di duga menderita Henoch-Schonlien purpura. Pengobatan pasien HSP dengan Prednison dengan dosis $2 \mathrm{mg} / \mathrm{kgBB} / \mathrm{hari}$ yang terbagi dalam tiga dosis. Pada hari ketiga purpura berkurang cenderung menipis dan nyeri enkle menghilang pada hari kelima. Bercak merah timbul, setelah terapi dihentikan selama 1 bulan. Penderita HSP $94 \%$ sembuh pada anak-anak dan $89 \%$ pada dewasa. Rekurnasi HSP lebih sering terjadi pada anak usia diatas 10 tahun dan biopsi ginjal harus dilakukan untuk menentukan terapi selanjutnya.

Kata kunci: henoch-schonlein purpura, steroid, palpable-purpura

\section{PENDAHULUAN}

Henoch-Schonlein purpura (HSP) adalah ruam berwarna merah atau ungu pada kulit karena terjadi peradangan pembuluh darah pada kulit, sendi, usus dan ginjal. Penanganan yang tepat dapat memulihkan penderita HSP dalam beberapa minggu. HSP tidak menular dan cenderung dialami oleh anak-anak yang berusia di bawah 10 tahun. Ruam biasanya terjadi pada bagian tubuh seperti pantat (bokong), tungkai atau sekitar siku. Selain itu, ruam bisa juga timbul pada tubuh bagian atas atau wajah. Gejala lain yang bisa ditimbulkan HSP adalah nyeri perut, nyeri sendi, demam, muntah, tinja dan air seni terdapat flek darah .

Penderita HSP sebagian besar mengalami inveksi virus atau bakteri pada tenggorokan dan paru-paru. Gangguan kekebalan tubuh pada penderita HSP diduga disebabkan oleh makanan, obat-obatan, cuaca dingin atau gigitan serangga. HSP yang parah dapat mengakibatkan terjadi komplikasi, sehingga perawatan harus dilakukan secara intensif di rumah sakit. Jika usus terlipat atau pecah, penedrita HSP harus dilakukan tindakan operasi.

\section{KASUS}

Seorang anak laki-laki umur 11 tahun dibawa ke tempat praktik dengan keluhan timbul bercak-bercak merah di kakinya sejak 3 hari sebelumnya. Semakin lama semakin bertambah banyak mengarah ke pantat. Tidak didapatkan rasa gatal pada bercak-bercak tersebut. Pergelangan kakinya terasa nyeri sekali sehingga tidak dapat berjalan. Tidak ada keluhan panas badan, mual maupun muntah, tetapi ulu hati terasa nyeri. Tidak ada keluhan perdarahan. Buang air besar (BAB) seperti biasa. Jumlah dan warna kencing juga seperti biasa. Riwayat makan sebelum timbulnya keluhan seperti biasa. Juga tidak mengonsumsi obat tertentu.Tidak didapatkan riwayat sakit seperti ini sebelumnya. Tidak didapatkan riwayat alergi makanan dan obat, serta riwayat perdarahan. 
Tetangga sekitarnya banyak yang sedang terkena demam berdarah dan infeksi Chikungunya. Penderita sudah diperiksakan di Puskesmas, dikatakan bahwa penderita terkena alergi. Tetapi setelah diberi obat anti alergi dan anti nyeri, keluhan tetap tidak ada perbaikan.

Dari pemeriksaan fisik didapatkan tanda vital yang stabil. Tekanan darah 95/60. Tidak didapatkan anemia, ikterus, sianosis, maupun sesak. Pada kepala dan leher tidak didapatkan edema palpebra maupun rash atau lesi. Pemeriksaan thorax juga dalam batas normal. Dari pemeriksaan abdomen didapatkan nyeri tekan di daerah epigastrium, tidak ada meteorismus, bising usus normal. Pada pemeriksaan ekstremitas, didapatkan banyak bercak kemerahan di regio cruris bilateral, dengan diameter bervariasi mulai $0,2-1 \mathrm{~cm}$ mulai daerah ankle sampai regio femoris. Lesi merah ini tidak tampak pucat pada saat ditekan, dan teraba lebih menonjol dibandingkan permukaan kulit yang lain. Didapatkan edema pada ankle bilateral, dan nyeri ankle yang bertambah hebat saat ditekan. Penderita diduga menderita Henoch-Schonlein Purpura. Penderita dirawat inap untuk dilakukan pemeriksaan penunjang, pemberian terapi dan sekaligus pemantauan terapi.

Hasil laboratorium:

Darah Lengkap: $\mathrm{Hb}$ 12,3 Hct 38,2Lekosit $6.890 \quad$ Plt 413.000

BUN 9,6 SK 0,51 CRP 5

Fungsi Koagulasi Normal

Hasil Urine Lengkap : Eritrosit 10-12, Lekosit 2, lain-lain masih dalam batas normal.

Penderita diberi steroid yaitu Prednison dengan dosis $2 \mathrm{mg} / \mathrm{kgBB} / \mathrm{hari}$ terbagi dalam 3 dosis. Sehari setelah terapi, nyeri sendi berkurang, sedangkan purpura masih belum ada perubahan. Pada hari ke-3 terapi, purpura mulai tampak menipis dan ada yang mulai menghilang; nyeri ulu hati sudah tidak didapatkan; dan nyeri sendi ankle sudah sangat berkurang. Ankle penderita sudah mulai bisa digerakkan, tetapi penderita masih belum kuat untuk berjalan. Nyeri pada ankle hilang sama sekali pada hari ke-5 terapi steroid, dan penderita sudah mulai bisa berdiri dan berjalan. Penderita dipulangkan pada hari ke-5 perawatan dengan membawa obat untuk dilanjutkan di rumah, dan direncanakan untuk pemeriksaan urine lengkap ulang secara berkala. Lebih kurang 2 bulan setelah terapi steroid dihentikan secara tappering-off, timbul bercak-bercak merah lagi di tungkainya disertai nyeri sendi ankle. Terjadi kekambuhan pada penderita ini.

\section{BAHASAN}

Pada penderita ini didapatkan lesi berwarna merah di kulit disertai keluhan nyeri perut di epigastrium dan nyeri sendi ankle. Apakah gejala dan tanda ini berdiri sendiri ataukah sebenarnya merupakan satu kesatuan tanda dari sebuah penyakit? Menjumpai keluhan nyeri epigastrium sangat dimungkinkan kecurigaan ke arah peningkatan asam lambung hingga terjadinya erosi dinding lambung. Diagnosa banding dari kondisi ini sangat beragam. Pada saat yang bersamaan, penderita ini juga mengeluh nyeri sendi yang hebat hingga tidak dapat berjalan. Nyeri sendi pada anak sangat jarang terjadi. Apabila didapatkan nyeri sendi, harus diteliti apakah didapatkan keluhan dan tanda yang lain. Pada penderita ini adanya purpura bisa menjadi awal mencari penyebabnya.

Lesi berwarna merah di kulit atau eritema bisa merupakan gambaranklinis yang bervariasi; bisa merupakansuatumakula, petechie, ecchymosis, urtikaria, dan lain-lain. Eritema ini juga bisa merupakan tanda dari berbagai penyakit[1]. Dalam menghadapi penderita dengankeluhan bercak merah di kulit, harus dipastikan terlebih dahulu bentukan apakah bercak tersebut. Hal ini bisa diketahui dengan melakukan pemeriksaan fisikyang teliti. Di samping ituperlujuga dicari keluhan dan tanda lain yang menyertai.

Bercak merah di kulit bisa merupakan manifestasi dari adanya vasodilatasi pembuluh darah kulit seperti yang terjadi pada kasus alergi, di mana karena adanya trigger, maka dikeluarkanlah histamin dari mast cell ke sirkulasi, kemudian terjadi cascade alergi dengan hasil akhir terjadinyavasodilatasi. Eritema yang disebabkan karena vasodilatasi pembuluh darah kulitini 
bisa dikenali denganmelakukan penekanan pada bercak tersebut. Apabila saat ditekan, bercak kemerahan tersebut menjadi pucat, maka eritema tersebut merupakan suatu akibat dari vasodilatasi. Hal ini akan berbeda pada eritema yang disebabkan karena adanya ekstravasasi darah ke kulitatau membran mukosa. Pada ekstravasasi eritrosit, maka bercak kemerahan yang timbul pada kulit tidak akan memucat apabila ditekan [1,2]. Penggunaan sebuah glass slide yang ditekankan pada lesi, dapat mempermudah dalam membedakan keduanya, yaitu eritema karena vasodilatasi (memucat dengan tekanan), atau karena ekstravasasi eritrosit (tetap merah) [2].

Pada kasus di atas, disebutkan bahwa bercak-bercak merah pada tungkai penderita tidak menjadi pucat pada saat ditekan. Hal ini mengindikasikan bahwa bercakmerah pada penderita ini merupakan akibat ekstravasasi eritrosit ke permukaan kulit. Ekstravasasi eritrosit di permukaan kulit ini memberi gambaran klinis berupa purpura. Purpura bisa terjadi karena hyper-dan hypocoagulablestates, disfungsi vascular dan faktor ekstravaskular [2]. Untuk mengetahui penyebab purpura pada kasus ini, maka perlu meneliti lebih detail jenis purpuranya dan melakukan pemeriksaan penunjang.

Purpura bisa teraba (palpable purpura) atau tidak teraba (flat/macular purpura). Macular purpura dibagi menjadi 2 (dua) bentukan berdasarkan ukuran, yaitu petechie (diameter $<3 \mathrm{~mm}$ ) dan ecchymosis (diameter $>5 \mathrm{~mm}$ ). Macular purpura merupakan tipe non-inflamasi, sedangkan palpable purpura merupakan tanda inflamasi dari pembuluh darah kecil di kulit (small cutaneous vessels) misalnya vasculitis. Inflamasi vaskuler menyebabkan kerusakan dinding vaskuler dan ekstravasasi eritrosit yang tampak sebagai purpura pada kulit. Palpable-purpura ini merupakan lesi yang khas dari vasculitis leukocytoclastic (small vessel vasculitis).

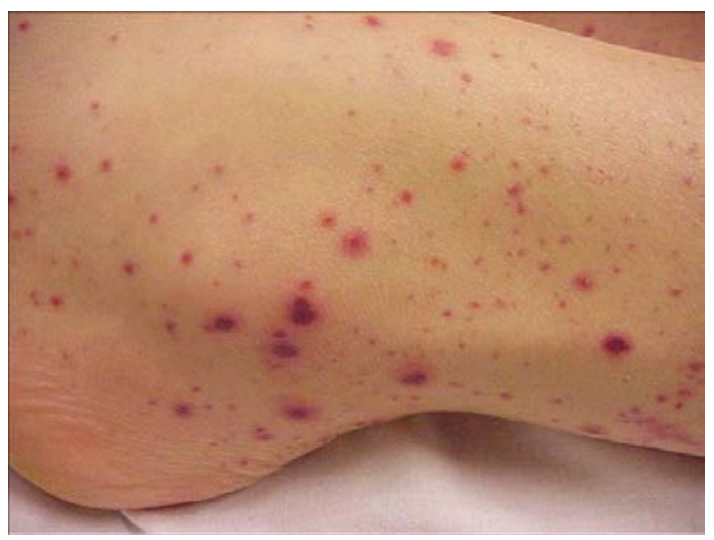

Gambar 1. Purpura [2].

Purpura yang didapatkan pada penderita ini dapat diraba (palpable-purpura), sehingga besar kemungkinan bahwa penyebab purpura di sini karena adanya vasculitis, bukan karena gangguan fungsi koagulasi. Hal ini ditunjang dengan adanya data laboratorium yang menunjukkan bahwa fungsi koagulasi penderita ini masih dalam batas normal.

Vasculitis diklasifikasikan berdasarkan ukuran pembuluh darah (kecil, sedang, besar atau mixed) [2]. Morfologi klinis yang dikorelasikan dengan pembuluh darah yang terkena adalah sebagai berikut:

- Pembuluh darah kecil: palpable purpura (urticarial lesions)

- Pembuluh darah kecil - sedang: subcutaneous nodules, purpura dan FIXED livedoreticularis (livedoracemosa)

- Pembuluh darah besar : claudication, ulceration dan necrosis

Beberapa penyakit kadang melibatkan lebih dari satu jenis ukuran pembuluh darah. Vaskulitis sistemik dapat mengenai pembuluh-pembuluh darah di organ-organ lain. Pada penderita ini manifestasi klinis yang timbul adalah palpable-purpura, sehingga jelas bahwa bahwa penyebab purpuranya adalah karena vaskulitis pembuluh darah kecil [2].

Small vessel vasculitis (leukocytoclastic vasculitis) bisa terjadi karena: 
- Henoch-Schonlein purpura

- Urticarial vasculitis

- Lain-lain yaitu idiopatik, keganasan, Rheumatologic, infeksi, akibat obat [3].

Penderita ini awalnya disangka mengalami alergi, tetapi hal ini tidak terbukti, baik dari anamnesis maupun outome setelah mendapat obat antihistamin. Kemungkinan mengalami infeksi Dengue atau Chikungunya perlu juga dicurigai, mengingat adanya insiden yang tinggi di daerah tempat tinggalnya dan didapatkannya perdarahan subkutan dan nyeri sendi hebat pada penderita ini. Tetapi kecurigaan ini tersingkirkan karena tidak ada riwayat panas dan hasil laboratorium Darah Lengkap yang masih dalam batas normal. Bahkan jumlah trombosit pada penderita ini justru lebih dari normal. Sehingga bisa dipastikan bahwa perdarahan subkutan yang terjadi pada penderita ini bukan karena faktor trombositopenia. Hal ini menyingkirkan juga diagnosis banding yang lain yaitu Immune Thrombocytopenic Purpura (ITP) di mana terjadi banyak perdarahan juga termasuk perdarahan sukbutan, namun rendahnya jumlah trombosit merupakan karakteristik penyebabnya [4].

Dari berbagai kemungkinan di atas, dan setelah menyingkirkan berbagai kemungkinan diagnosa lain, maka Henoch-Schonlein Purpura (HSP) adalah penyakit yang paling mungkin dialami oleh penderita ini. Selain purpura juga didapatkan keluhan lain pada anak ini yaitu nyeri perut dan nyeri sendi. Henoch-Schonlein purpura (HSP) adalah penyakit vaskulistik sistematik (inflamasi vaskuler) ditandai dengan deposisi komplek imun yang terdiri dari IgA pada kulit ginjal. Penyakit ini disebut Anaphylactoid purpura, Purpura rheumatic, SchonleinHenoch purpura $[5,8]$.

Penyakit yang tergolong langka ini (insiden pada anak sekitar 20 setiap 100.000 anak) tidak menular dan tidak diturunkan di dalam keluarga. Epidemiologi HSP terjadi lebih banyak pada anak dari pada dewasa, dan biasanya terjadi sesudah infeksi saluran nafas atas. Setengah dari kasus berusia dibawah 6 tahun, $90 \%$ dibawah usia 10 tahun. Laki-laki dua kali lebih sering daripada perempuan [9].

Penyebab HSP yang pasti belum diketahui, bisa terjadi setelah infeksi virus/kuman, dan reaksi obat. HSP dapat terjadi setelah infeksi Streptococci ( $\beta$-haemolytic, Lancefield group A), Hepatitis B, herpes simplex virus, parvovirus B19, Coxsackievirus, Adenovirus, Helicobacter pylori, measles, mumps, rubella, mycoplasma. Obat yang dilaporkan menyebabkan HSP, biasanya reaksi idiosynkrasi: Vancomycin , Cefuroxime, ACE inhibitors enalapril dan captopril, diclofenac, Ranitidine, streptokinase. Pemeriksaan patologi menunjukkan endapan anti bodi IgA1 polimer yang menyebabkan vaskulitis. Belum jelas apakah karena produksi berlebihan dari sumsum tulang atau Gl, atau berkurangnya klirens dari sirkulasi [5] [8]. Pada penderita ini tidak didapatkan adanya riwayat sakit infeksi sebelumnya maupun riwayat minum obat, sehingga tidak bisa diperkirakan faktor pemicunya.

Gejala yang tipikal pada HSP adalah palpable-purpura, nyeri sendi dan nyeri abdomen $[5,6]$. Tetapi karena HSP bisa menyerang semua organ tubuh, maka pemeriksaan fisik yang menyeluruh harus dilakukan. Pemeriksaan fisik pada HSP meliputi:

1. Pemeriksaan kulit (pada umumnya merupakan tanda awal HSP), berupa makula eritematous atau lesi urtikaria yang berkembang kemudian menjadi pal pable-purpura; secara tipikal bersifat simetris. Purpura terjadi pada semua kasus. Purpura khas terlihat pada tungkai bawah dan pantat. Bisa juga terjadi di bagian tubuh atas dan wajah. Telah dijelaskan di atas bahwa kondisi itu sebenarnya merupakan perdarahan subkutan (ekstravasasi eritrosit) akibat pembuluh darah yang mengalami peradangan [3].

2. Pada pemeriksaan sendi didapatkan artralgia dan pembengkakan. Artralgia merupakan gambaran klinis pada $25 \%$ kasus. Sendi mengalami bengkak, lunak, dan sangat nyeri. Tetapi kondisi sendi yang hangat, eritema, dan adanya efusi bukan tipikal dari HSP. Sendi lutut dan ankle yang paling sering terkena. Pada kondisi yang jarang dapat mengenai jari-jari dan pergelangan tangan. Temuan ini bersifat transient, tetapi dapat terjadi lagi selama penyakit aktif. Nyeri sendi dan arthritis terjadi pada $80 \%$ 
kasus, Nyeri sendi yang terkena adalah ankle, lulut, dan siku; nyeri bersifat nonerosive, dan tidak menyebabkan deformitas permanen [5,8].

3. Temuan di Gastrointestinal (Gl) bisa berupa abdominal pain pada $62 \%$ kasus; bisa disertai mual, muntah, melena, bloody diarrhea, hematemesis, ulkus duodenum. Perdarahan gastrointestinal terjadi pada 33\% kasus, dan kadang terjadi invaginasi $[10,12]$.

4. Kelainan ginjal berupa lesi glomerulus akut, meliputi mesangial hypercellularity, endocapillary proliferation, necrosis, cellular crescents, dan leukocyte infiltration. Kurang lebih $40 \%$ kasus berkembang menjadi nefritis yang ditandai adanya hematuria, umumnya terjadi 4-6 minggu sejak munculnya purpura. Separuhnya mengalami proteinuria. Seperdelapannya mengalami komplikasi ginjal yang cukup berat yaitu Sindroma Nefrotik. Kelainan urinalisis biasanya berlangsung lama, tetapi hanya $1 \%$ yang menjadi Chronic Renal Disease. Meskipun patogenesisnya belum jelas, beberapa studi mengatakan bahwa galactose-deficient IgA1 (Gd-lgA1) yang dikenali oleh antiglycan antibodies menyebabkan pembentukan circulating immune complexes dan deposisi mereka di glomerulus menginduksi renal injury pada HSP. Beratnya renal involvement merupakan faktor penentu outcome jangka panjang anak-anak HSP dengan nefritis (HSPN) $[13,14]$.

5. Temuan lain - Vasculitis bisa terjadi pada myocardium maupun paru $[15,16]$; vasculitis pada central nervous system (CNS) dan intracranial hemorrhage [17,18]; stenosis ureteritis, penile edema, scrotal oedema atau orchitis [19,20]; bilateral subperiosteal orbital hematomas; adrenal hematomas; acute pancreatitis sebagai gambaran klinis tunggal bisa terjadi meskipun sangat jarang [21]; perubahan cystic pada ovarium.

Pada penderita ini trias gejala muncul semua yaitu palpable-purpura, nyeri sendi dan nyeri abdomen, sehingga memenuhi kriteria diagnosis berdasarkan klasifikasi terbaru European League Against Rheumatism (EULAR) dan Pediatric Rheumatology Society (PReS) 1994 yaitu palpable-purpura (merupakan kriteria mutlak), bersama satu atau lebih keadaan berikut $[22,24]$ :

1. nyeri perut akut

2. nyeri sendi akut pada sendi manapun

3. perdarahan gastrointestinal

4. endapan IgA pada biopsi kulit

5. dan kelainan ginjal (ditemukannya darah atau protein dalam urine).

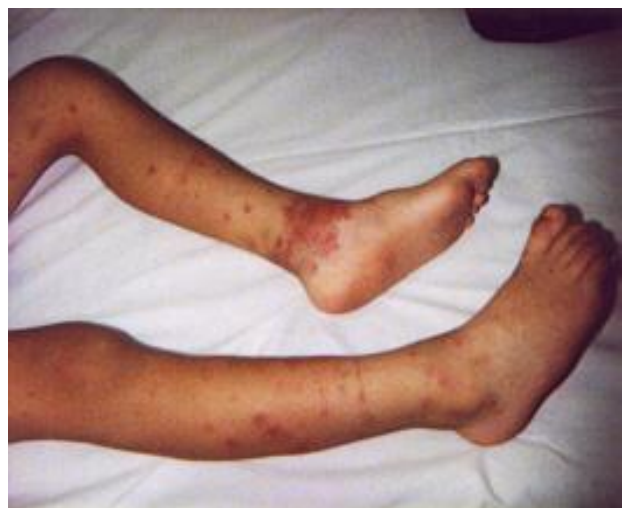

Gambar 2. Purpura di ektremitas inferior [2].

Setelah menegakkan diagnosis HSP, pemeriksaan penunjang lainnya juga penting dilakukan, terutama untuk melihat adanya komplikasi gangguan ginjal. Beberapa jenis pemeriksaan tersebut meliputi [7] [8]:

1. Pemeriksaan darah tepi:

a. peningkatan serum creatinin dan urea pada pasien dengan kelainan ginjal 
b. peningkatan IgA pada $50 \%$ kasus

c. peningkatan platelet membedakan dengan penyakit purpura lain misalnya ITP dan thrombotic thrombocytopenic purpura.

2. Biopsi Ginjal: untuk diagnosis dan berat ringan penyakit. Ditemukan peningkatan sel dan deposit Ig pada mesangium, lekosit dan adanya cresent.

3. Direct immunofluorescence menggunakan anti-IgA antibody pada spesimen kulit. Akan tampak endapan IgA pada dinding kapiler kecil.

Pada penderita ini didapatkan hematuria mikroskopis tanpa adanya penurunan fungsi ginjal. Tekanan darah juga masih dalam batas normal. Bisa dikatakan bahwa manifestasi keterlibatan ginjal pada penderita ini masih ringan. Tetapi pada penderita ini diberikan terapi steroid.

Dikatakan bahwa sebagian besar kasus HSP bisa sembuh sendiri tidak memerlukan pengobatan, tetapi sebagian berulang pada $1 / 3$ kasus dan menyebabkan kerusakan ginjal pada $1 / 100$ kasus. Tata laksana pada umumnya untuk HSP adalah sebagai berikut $[7,8]$ :

- Sebagian besar kasus tidak perlu diobati karena sangat sering yang sembuh sendiri.

- Obat analgesik dan anti inflamasi non-steroid diperlukan untuk mengatasi nyeri perut dan nyeri sendi.

- Steroid pada umumnya dihindari. Akan tetapi kalau diberikan pada fase dini, maka lama sakit bisa diperpendek, nyeri perut dan komplikasi ginjal bisa diatasi dengan baik.

- Seringnya komplikasi ginjal mengharuskan dilakukan biopsi ginjal; berbagai pengobatan diberikan berkisar pada steroid oral kombinasi metil prednisolon IV, cyclophosphamid dan dipiridamol diikuti prednisone. Regimen lain termasuk steroid/azathioprine, steroid/cyclophosphamid kadang dipakai (dengan atau tanpa heparin dan warfarin).

- Intravenous immunoglobulin (IVIG)

- Cortisone intravena juga efektif baik untuk baik purpura dan komplikasi ginjal, pengobatan ini memerlukan 3 kali/hari tiap bulan dalam 1 tahun, dan selama 2 tahun untuk kasus yang berat.

Sepertinya pertimbangan pemberian steroid oral pada penderita ini adalah untuk memperpendek lama sakit dan mengurangi risiko komplikasi pada ginjal. Hal ini dibenarkan asalkan pemantauan terhadap efek samping steroid dilakuan secara ketat. Pada penderita ini awalnya dilakukan rawat inap karena tidak bisa berjalan sama sekali dan masih dikhawatirkan ada penyebab lain dari masalah ini. Tetapi dalam pengamatan lebih lanjut ternyata keluhan nyeri sendi dan perut sangat cepat membaik dengan pemberian steroid yaitu pada hari ke-2 perawatan. Demikian juga purpura juga cepat memudar dan menghilang setelah beberapa hari. Dengan demikian diagnosis HSP tidak diragukan lagi meskipun pada penderita ini tidak dilakukan pemeriksaan baku emas yaitu biopsi kulit atau ginjal. Cara penegakan diagnosis secara klinis seperti ini bisa diterima yaitu berdasarkan klinis sesuai klasifikasi EULAR seperti tersebut di atas.

\section{SIMPULAN}

Prognosis kasus HSP pada umumnya baik, yaitu bisa sembuh $94 \%$ pada anak, $89 \%$ pada dewasa. Pada anak dibawah 10 tahun rekurensi terjadi pada $1 / 3$ kasus setelah 4 bulan pertama terjadinya serangan. Rekurensi lebih sering pada anak yang lebih besar $[7,8]$. Penderita dalam kasus ini berusia 11 tahun saat pertama kali mengalami keluhan dengan didapatkan hematuria mikroskopis. Dalam perjalanannya didapatkan rekurensi 1 bulan setelah terapi steroid. Untuk kondisi seperti ini, biopsi ginjal harus dilakukan untuk melihat kelainan yang terjadi dan menentukan jenis terapi selanjutnya.

PUSTAKA ACUAN 
1. Frigas $E$, Park MA. Acute urticaria and angioedema: diagnostic and treatment considerations. Am J Clin Dermatol. 2009. 10(4):239-50

2. http://www.dermatology.ucsf.edu/education_training/140.01Clinical_Dermatology/MODUL ES\%20UCSF/Petechia\%20Purpura\%20Vasculitis.pdf

3. Jennette JC, Falk RJ, Bacon PA, et al. 2012 revised International Chapel Hill Consensus Conference Nomenclature of Vasculitides. Arthritis Rheum 2013; 65:1.

4. Sandler SG, Tutuncuoglu SO. Immune thrombocytopenic purpura - current management practices. Expert Opin Pharmacother. 2004 Dec.

5. Yang YH, Yu HH, Chiang BL. The diagnosis and classification of Henoch-Schönlein purpura: an updated review. Autoimmun Rev 2014; 13:355.

6. Dillon MJ. Henoch-Schönlein purpura: recent advances. Clin Exp Rheumatol 2007; 25:S66.

7. Peru H, Soylemezoglu O, Bakkaloglu SA, et al. Henoch Schonlein purpura in childhood: clinical analysis of 254 cases over a 3-year period. Clin Rheumatol 2008; 27:1087.

8. McCarthy HJ, Tizard EJ. Clinical practice: Diagnosis and management of Henoch-Schönlein purpura. Eur J Pediatr. 2010 Jun. 169(6):643-50.

9. Piram M, Mahr A. Epidemiology of immunoglobulin A vasculitis (Henoch-Schönlein): current state of knowledge. Curr Opin Rheumatol 2013; 25:171.

10. Chang WL, Yang YH, Lin YT, Chiang BL. Gastrointestinal manifestations in Henoch-Schönlein purpura: a review of 261 patients. Acta Paediatr 2004; 93:1427.

11. Nathan K, Gunasekaran TS, Berman JH. Recurrent gastrointestinal Henoch-Schönlein purpura. J Clin Gastroenterol 1999; 29:86.

12. Yu JE, Mancini AJ, Miller ML. Intussusception in an infant with acute hemorrhagic edema of infancy. Pediatr Dermatol 2007; 24:61.

13. Watanabe T, Sato Y. Renal involvement and hypocomplementemia in a patient with acute hemorrhagic edema of infancy. Pediatr Nephrol 2007; 22:1979.

14. Ghrahani R, Ledika MA, Sapartini G, Setiabudiawan B. Age of onset as a risk factor of renal involvement in Henoch-Schönlein purpura. Asia Pac Allergy 2014; 4:42.

15. Nadrous HF, Yu AC, Specks U, Ryu JH. Pulmonary involvement in Henoch-Schönlein purpura. Mayo Clin Proc 2004; 79:1151.

16. Vats KR, Vats A, Kim Y, et al. Henoch-Schönlein purpura and pulmonary hemorrhage: a report and literature review. Pediatr Nephrol 1999; 13:530.

17. Belman AL, Leicher CR, Moshé SL, Mezey AP. Neurologic manifestations of SchoenleinHenoch purpura: report of three cases and review of the literature. Pediatrics 1985; 75:687.

18. Misra AK, Biswas A, Das SK, et al. Henoch-Schonlein purpura with intracerebral haemorrhage. J Assoc Physicians India 2004; 52:833.

19. Chamberlain RS, Greenberg LW. Scrotal involvement in Henoch-Schönlein purpura: a case report and review of the literature. Pediatr Emerg Care 1992; 8:213.

20. Ha TS, Lee JS. Scrotal involvement in childhood Henoch-Schönlein purpura. Acta Paediatr 2007; 96:552.

21. Cheung KM, Mok F, Lam P, Chan KH. Pancreatitis associated with Henoch-Schonlein purpura. J Paediatr Child Health 2001; 37:311.

22. Mills JA, Michel BA, Bloch DA, et al. The American College of Rheumatology 1990 criteria for the classification of Henoch-Schönlein purpura. Arthritis Rheum 1990; 33:1114.

23. Ozen S, Ruperto N, Dillon MJ, et al. EULAR/PReS endorsed consensus criteria for the classification of childhood vasculitides. Ann Rheum Dis 2006; 65:936.

24. Ozen S, Pistorio A, lusan SM, et al. EULAR/PRINTO/PRES criteria for Henoch-Schönlein purpura, childhood polyarteritis nodosa, childhood Wegener granulomatosis and childhood Takayasu arteritis: Ankara 2008. Part II: Final classification criteria. Ann Rheum Dis 2010; 69:798. 